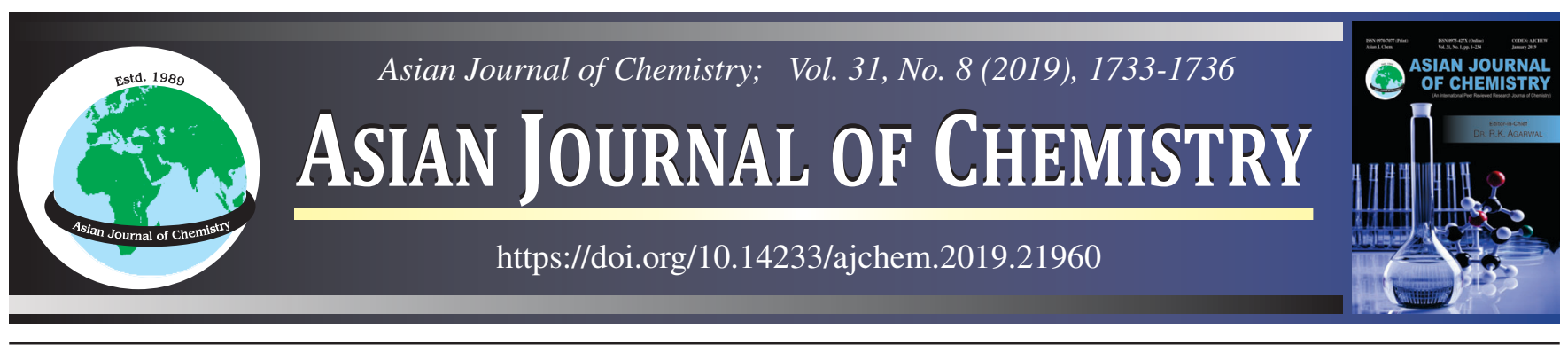

\title{
A Novel DNA and Dengue Virus Protein Binding of Antipyridine Based Copper and Zinc Metal Complexes through Molecular Docking Studies
}

\author{
K.N. Gita ${ }^{1, *}$, V. Chandrasekaran ${ }^{2}$ and P. Akilan ${ }^{2}$
}

${ }^{1}$ Department of Chemistry, Government Arts College for Women, Salem-636008, India

${ }^{2}$ Department of Chemistry, Government Arts College (Autonomous), Salem-636007, India

*Corresponding author: E-mail: gitakn27@gmail.com

Received: 25 January 2019;

Accepted: 18 March 2019;

Published online: 28 June 2019;

AJC-19444

The $\mathrm{Cu}$ (II) and $\mathrm{Zn}$ (II) complexes were synthesized using Schiff base ligand by refluxing with $\mathrm{CuCl}_{2}$ and $\mathrm{ZnCl}_{2}$. A Schiff base ligand (L) was synthesized by condensing $o$-vanillin and 4-aminoantipyrine. The synthesized ligand and metal complexes were characterized by IR and mass spectrometry. The synthesized $\mathrm{Cu}$ (II) and $\mathrm{Zn}$ (II) metal complexes were especially docked with human DNA (PDB I.D: 1BNA) and dengue protein virus (PDB ID: $2 \mathrm{VBC}$ ) using auto dock software tools version 1.5.6 and pymol. The binding of the ligand and biomolecule in grid point value of $\mathrm{x} \times \mathrm{y} \times \mathrm{z}$ directions of $90 \times 90 \times 90$ and a grid space group value of $0.380 \AA$. The binding energy values of $\mathrm{Cu}$ (II) and $\mathrm{Zn}$ (II) complexes were respectively -7.1 and $-7.4 \mathrm{kcal} \mathrm{mol}^{-1}$ towards NS3 protease-helicase, while the binding energy values of $\mathrm{Cu}(\mathrm{II})$ and $\mathrm{Zn}$ (II) complexes were found to be -8.5 and $-8.2 \mathrm{kcal} \mathrm{mol}^{-1}$, respectively towards B-DNA.

Keywords: $o$-Vanillin, 4-Aminoantipyrine, Schiff base ligand, Protein binding.

L - - - - - - - - - - - - - - - -

\section{INTRODUCTION}

Dengue illness caused by dengue virus infection has risen as an endemic in more than 100 nations, particularly in the tropical and subtropical areas, with in excess of 2.5 billion individuals or $40 \%$ of the total population in danger zone. dengue virus mostly transmitted by Aedes aegypti mosquito. Dengue infection is kept up in a cycle that includes human and the mosquito [1-5]. The disease produces clinical ailment running from innocuous run of the mill fever to a deadly hemorrhagic fever (DHF) portrayed by slim spillage and thrombocytopenia. In addition, it might show into the disappointment of the flow framework and stun, named as dengue stun disorder (DSS) that may lead to death [6-11]. It is evaluated that 100 million dengue fever (DF) cases happen every year and around 2,50,000-5,00,000 cases are of the serious shape dengue hemorrhagic fever (DHF) [12-16]. Dengue virus is one of the members of the family of Flaviviridae which consists of four viral serotypes those are, DEN-1, DEN-2, DEN-3 and DEN-4 [17]. Deep-rooted resistance to one serotype will avert contamination by the same serotype yet does not give insurance from an auxiliary disease of an alternate serotype. The immune response subordinate improvement (ADE) pathogenesis speculation suggests that optional contamination with an alternate serotype builds the danger of creating dengue hemorrhagic fever and dengue stun disorder [18]. So it is very necessary to develop a drug towards dengue. In this paper, we have synthesized biological important 4-aminoantipyrine and $o$-vanillin backbone Schiff base (L) was synthesized and its $\mathrm{Cu}(\mathrm{II})$ and $\mathrm{Zn}$ (II). The metal complexes were characterized by IR and Mass spectrometry. The synthesized complexes were very active in nature towards DNA and dengue virus protein binding.

\section{EXPERIMENTAL}

All the chemicals used in the synthesis were either of AR grade or chemically pure grade. $o$-Vanillin, 4-aminoantipyrine, Copper chloride and zinc chloride were purchased from Sigma Aldrich. Solvents were purchased from Merck and used as the same purity.

Synthesis of Schiff base ligand (L): An acetonitrile solution of $o$-vanillin $(1 \mathrm{mmol})$ and 4 -aminoantipyrine $(1 \mathrm{mmol})$ were refluxed. After $1 \mathrm{~h}$, a yellow solid appeared. Collect the solid mass using filtration and washed with $10 \mathrm{~mL}$ of acetonitrile

This is an open access journal, and articles are distributed under the terms of the Attribution 4.0 International (CC BY 4.0) License. This license lets others distribute, remix, tweak, and build upon your work, even commercially, as long as they credit the author for the original creation. You must give appropriate credit, provide a link to the license, and indicate if changes were made. 
and chloroform mixture. The yellow solid Schiff base is highly soluble in methanol (Scheme-I).

Synthesis of copper(II) and zinc(II) metal complexes: Schiff base ligand ( $1 \mathrm{mmol}$ ) was dissolved in $4 \mathrm{~mL}$ of methanol and copper chloride/zinc chloride ( $1 \mathrm{mmol}$ ) was dissolved in $5 \mathrm{~mL}$ of methanol and added drop-wise to ligand and the solution were refluxed. Green colour and yellow colour insoluble solid mass were appeared within $1 \mathrm{~h}$ respectively for copper and zinc complexes, respectively. The solid mass was filtered and washed with $5 \mathrm{~mL}$ methanol (Scheme-I). $\mathrm{Cu}$ (II) complex: m.f.: $\mathrm{C}_{19} \mathrm{H}_{18} \mathrm{~N}_{3} \mathrm{O}_{3} \mathrm{ClCu}$, m.w.: 435.36. Elemental analysis found \%: C, 52.42; H, 4.17; Cl, 8.14; Cu, 14.60; N, 9.65; O, 11.02. $\mathrm{Zn}(\mathrm{II})$ complex: m.f.: $\mathrm{C}_{19} \mathrm{H}_{18} \mathrm{~N}_{3} \mathrm{O}_{3} \mathrm{ClZn}$, m.w.: 437.23. Elemental analysis found \%: C, 52.19; $\mathrm{H}, 4.15 ; \mathrm{Cl}, 8.11 ; \mathrm{N}, 9.61 ; \mathrm{O}$, 10.98; Zn, 14.96.

Schiff base ligand and its metal complexes were also confirmed by FT-IR and mass spectrometry. The values of IR spectroscopy was given in Table-1. From IR spectra (Fig. 1) of Schiff base ligand, the peak at $3455 \mathrm{~cm}^{-1}$ represents $o$-vanillin $\mathrm{O}-\mathrm{H}$ stretching peak which reacts with the metal ion and it shifted towards 3427 and $3412 \mathrm{~cm}^{-1}$ for $\mathrm{Cu}$ and $\mathrm{Zn}$ complexes. The azomethine peak also shifted due to the complexation. Carbonyl peak also shifted which indicates the carbonyl group, participation in the complexation.

\section{TABLE-1}

FT-IR $\left(\mathrm{cm}^{-1}\right)$ SPECTRAL VALUES OF SCHIFF BASE AND ITS Cu(II) AND Zn(II) COMPLEXES

\begin{tabular}{ccccc}
\hline Sample & $v(\mathrm{O}-\mathrm{H})$ & $v(\mathrm{C}=\mathrm{N})$ & $v(\mathrm{C}=\mathrm{O})$ & $v(\mathrm{M}-\mathrm{N})$ \\
\hline Ligand $(\mathrm{L})$ & 3455 & 1658 & 1705 & - \\
$\mathrm{Cu}+\mathrm{L}$ & 3427 & 1647 & 1682 & 498 \\
$\mathrm{Zn}+\mathrm{L}$ & 3412 & 1645 & 1679 & 512 \\
\hline
\end{tabular}

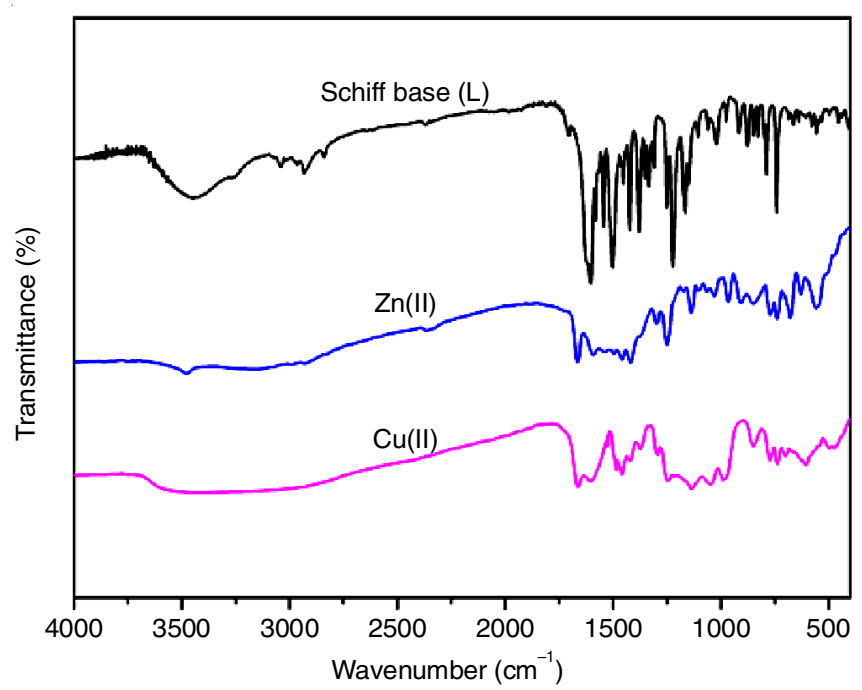

Fig. 1. FT-IR spectra for Schiff base (L) and its $\mathrm{Cu}(\mathrm{II})$ and $\mathrm{Zn}$ (II) complexes

The total mass of ligand is 337. The LC-MS spectra of ligand having a peak at $338.053(100 \%)$ which indicates L+1 spectra of the ligand (Fig. 2a). ESI-MS spectra of $\mathrm{L}+\mathrm{Cu}$ having a peak at $436.19(100 \%)$ which shows $\mathrm{M}+1$ of a copper complex (Fig. 2b) and ESI-MS spectra of L+Zn having a peak at 438.67 (100 $\%$ ) shows $\mathrm{M}+1$ of the metal complex (Fig. 2c).

Molecular docking study: Using Molecular docking study we can predict the binding nature of the drug towards biomolecules theoretically. Molecular docking is one of the Greenway monitor methods. The synthesized copper and zinc complexes were docked with dengue NS3 protease-helicase bi-functional enzyme (PDB ID: 2VBC) and B-DNA (PDB ID: 1BNA) using Auto Dock tools version 1.5.6, pymol and Discovery studio<smiles>COc1cccc(/C=N/c2c(C)n(C)n(-c3ccccc3)c2=O)c1O</smiles>

Scheme-I: Synthesis of Schiff base ligand and its $\mathrm{Cu} / \mathrm{Zn}$ metal complexes 

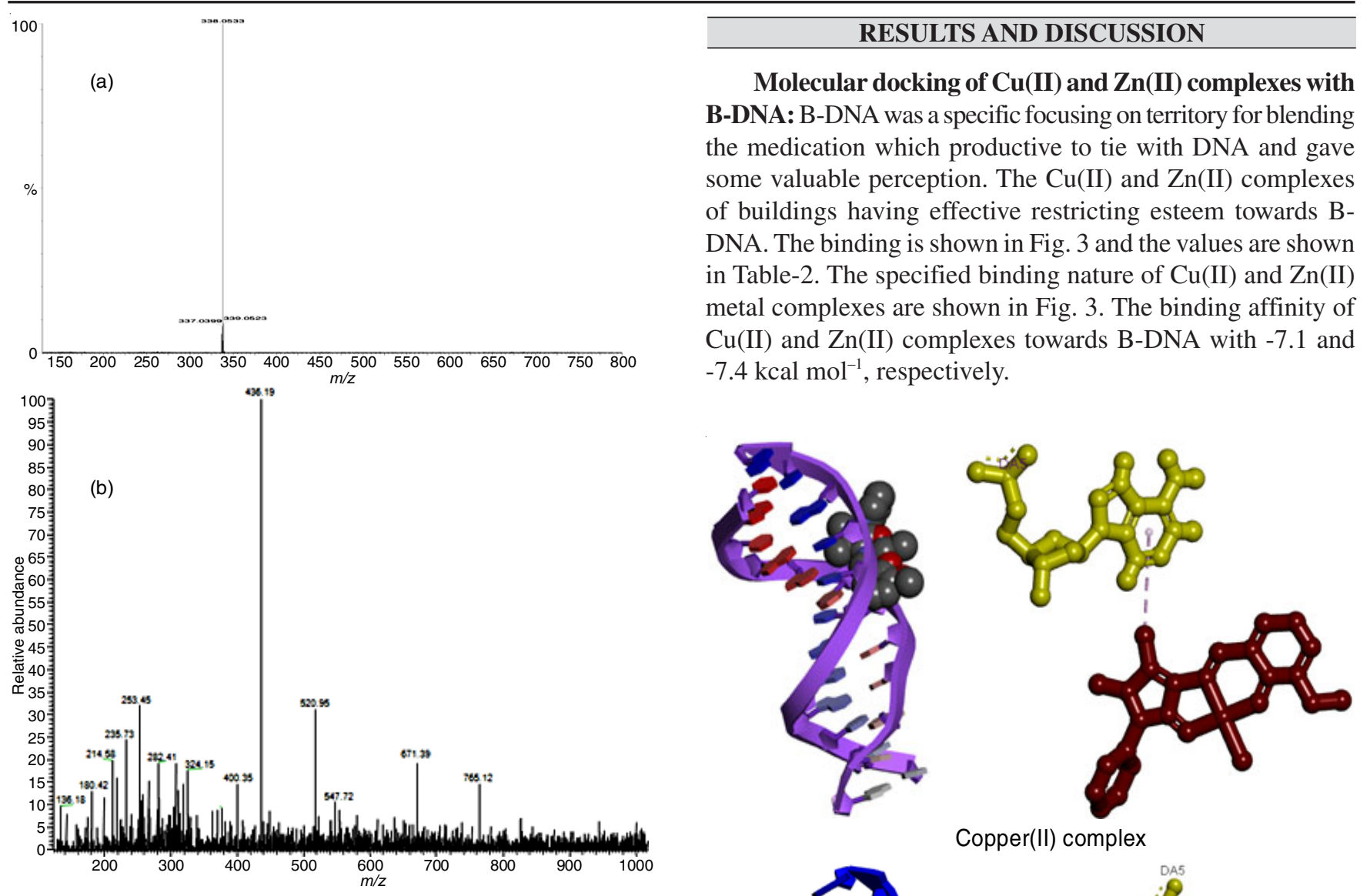

\section{RESULTS AND DISCUSSION}

Molecular docking of $\mathrm{Cu}(\mathrm{II})$ and $\mathrm{Zn}$ (II) complexes with B-DNA: B-DNA was a specific focusing on territory for blending the medication which productive to tie with DNA and gave some valuable perception. The $\mathrm{Cu}$ (II) and $\mathrm{Zn}$ (II) complexes of buildings having effective restricting esteem towards BDNA. The binding is shown in Fig. 3 and the values are shown in Table-2. The specified binding nature of $\mathrm{Cu}$ (II) and $\mathrm{Zn}$ (II) metal complexes are shown in Fig. 3. The binding affinity of $\mathrm{Cu}$ (II) and $\mathrm{Zn}(\mathrm{II})$ complexes towards B-DNA with -7.1 and $-7.4 \mathrm{kcal} \mathrm{mol}^{-1}$, respectively.
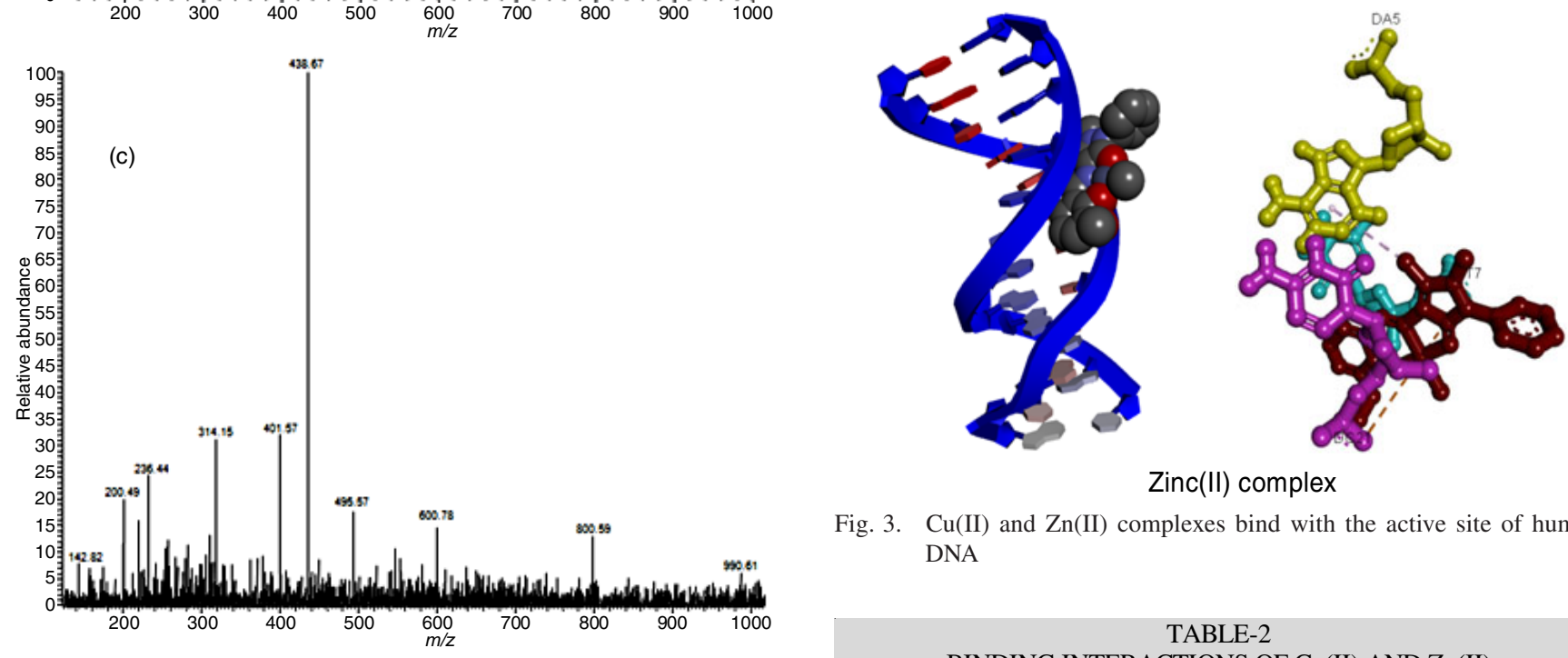

Zinc(II) complex

Fig. 3. $\mathrm{Cu}(\mathrm{II})$ and $\mathrm{Zn}$ (II) complexes bind with the active site of human DNA

\begin{tabular}{ccccc}
\multicolumn{5}{c}{ TABLE-2 } \\
\multicolumn{5}{c}{ BINDING INTERACTIONS OF Cu(II) AND Zn(II) } \\
COMPLEX WITH HUMAN DNA \\
\hline \multirow{2}{*}{ Complex } & $\begin{array}{c}\text { Acceptor } \\
\text { group }\end{array}$ & $\begin{array}{c}\text { Donor } \\
\text { group }\end{array}$ & $\begin{array}{c}\text { Binding energy } \\
\left(\mathrm{kcal} \mathrm{mol}^{-1}\right)\end{array}$ & $\begin{array}{c}\text { Distance } \\
(\AA)\end{array}$ \\
\hline \multirow{2}{*}{$\mathrm{Cu}+\mathrm{L}$} & $\mathrm{C} 15$ & DA5 & -7.1 & 4.72 \\
& $\mathrm{C} 15$ & DA5 & -72 \\
\hline \multirow{2}{*}{$\mathrm{Zn+L}$} & $\mathrm{Zn26}$ & DT7 & -7.4 & 5.57 \\
& $\mathrm{Zn26}$ & DC21 & & 5.47 \\
\hline
\end{tabular}

Molecular docking of $\mathrm{Cu}(\mathrm{II})$ and $\mathrm{Zn}$ (II) complexes with NS3 protease-helicase: NS3 protease-helicase (dengue virus protein) was docked with $\mathrm{Cu}$ (II) and $\mathrm{Zn}$ (II) metal complexes. NS3 protease-helicase is considered to be a receptor and the $\mathrm{Cu}$ (II) and $\mathrm{Zn}$ (II) metal complexes were considered to be a ligand. The binding nature is shown in Fig. 4. The selected 
binding of complexes with amino acid residue is shown in Fig. 4 and the binding nature with distance is shown in Table3. The binding affinity of $\mathrm{Cu}(\mathrm{II})$ and $\mathrm{Zn}$ (II) complexes towards NS3 protease-helicase with -8.5 and $-8.2 \mathrm{kcal} \mathrm{mol}^{-1}$, respectively.
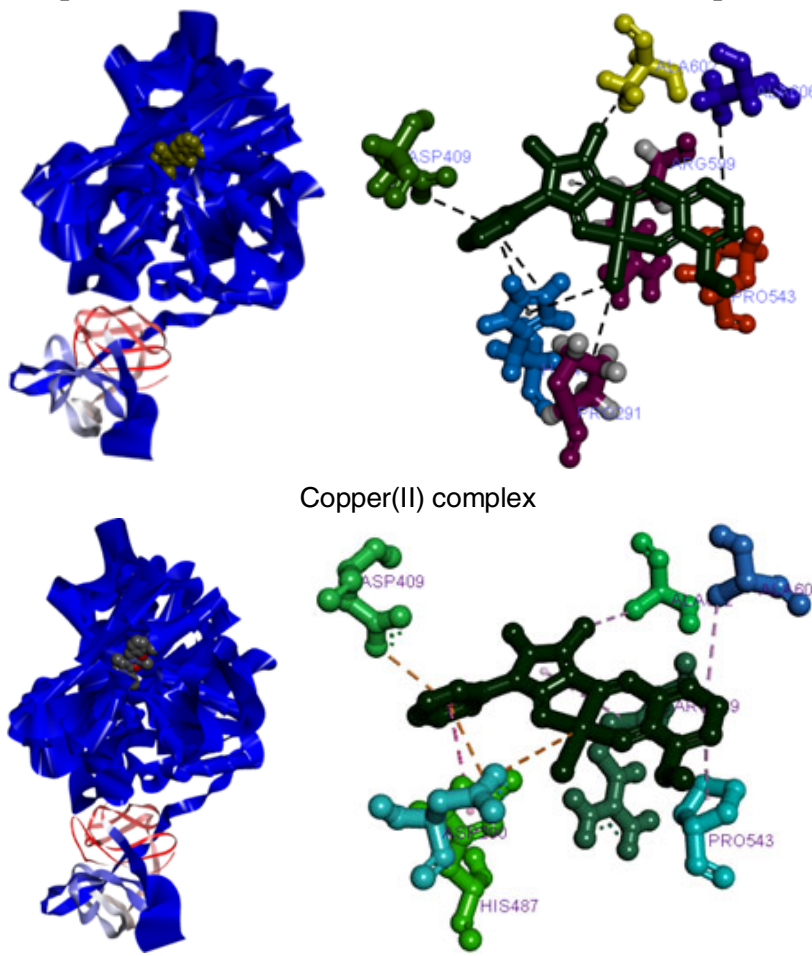

Copper(II) complex

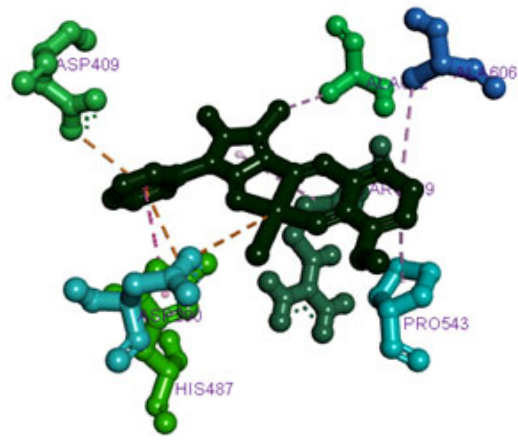

Zinc(II) complex

Fig. 4. $\mathrm{Cu}(\mathrm{II})$ and $\mathrm{Zn}(\mathrm{II})$ complexes bind with selective Nucleotide of NS3 protease-helicase

\begin{tabular}{ccccc}
\multicolumn{5}{c}{ TABLE-3 } \\
\multicolumn{5}{c}{$\begin{array}{c}\text { BINDING INTERACTIONS OF Cu(II) AND Zn(II) } \\
\text { COMPLEX WITH NS3 PROTEASE-HELICASE }\end{array}$} \\
\hline \multirow{2}{*}{ Complex } & $\begin{array}{c}\text { Acceptor } \\
\text { group }\end{array}$ & $\begin{array}{c}\text { Donor } \\
\text { group }\end{array}$ & $\begin{array}{c}\text { Binding energy } \\
\left(\mathrm{kcal} \mathrm{mol}^{-1}\right)\end{array}$ & $\begin{array}{c}\text { Distance } \\
(\AA)\end{array}$ \\
\hline \multirow{5}{*}{$\mathrm{Cu}+\mathrm{L}$} & C16-21 & ALA606 & & 5.24 \\
& Cl27 & ASP290 & & 3.70 \\
& C6-11 & HIS487 & -8.5 & 4.32 \\
& C6-11 & ASP409 & & 3.98 \\
& C16-21 & PRO543 & & 4.26 \\
\hline \multirow{5}{*}{$\mathrm{Zn+L}$} & Zn26 & ASP290 & & 5.31 \\
& N4 & ARG599 & & 3.72 \\
& C15 & ALA606 & -8.2 & 5.24 \\
& C6-11 & HIS487 & & 4.69 \\
& ASP409 & & 3.97 \\
\hline
\end{tabular}

\section{Conclusion}

A novel Schiff base ligand (L) was synthesized using $o$ vanillin and 4-aminoantipyrine. $\mathrm{Cu}(\mathrm{II})$ and $\mathrm{Zn}$ (II) metal complexes were synthesized using Schiff base ligand by refluxing with $\mathrm{CuCl}_{2}$ and $\mathrm{ZnCl}_{2}$. The synthesized Schiff base ligand and its metal complexes were characterized by IR and Mass spectrometry. The synthesized $\mathrm{Cu}(\mathrm{II})$ and $\mathrm{Zn}$ (II) metal complexes were docked with B-DNA (PDB ID: 1BNA) and dengue NS3 protease-helicase. The binding energy values of the $\mathrm{Cu}$ (II) and $\mathrm{Zn}$ (II) complexes were respectively -7.1 and $-7.4 \mathrm{kcal} \mathrm{mol}^{-1}$ towards NS3 protease-helicase. The binding energy values of $\mathrm{Cu}$ (II) and $\mathrm{Zn}$ (II) complexes respectively -8.5 and $-8.2 \mathrm{kcal} \mathrm{mol}^{-1}$ towards B-DNA.

\section{CONFLICT OF INTEREST}

The authors declare that there is no conflict of interests regarding the publication of this article.

\section{REFERENCES}

1. S. Melino and M. Paci, FEBS J., 274, 2986 (2007); https://doi.org/10.1111/j.1742-4658.2007.05831.x

2. K. Wichapong, A. Nueangaudom, S. Pianwanit, W. Sippl and S. Kokpol, Trop. Biomed., 30, 388 (2013).

3. F.A. Murphy, B.W.J. Mahy and M.H.V. van Regenmortel, Epidemiology of Human and Animal Viral Diseases, in Encycl. Virol., pp. 140-148 (2008).

4. E. Mastrangelo, M. Milani, M. Bollati, B. Selisko, F. Peyrane, V. Pandini, G. Sorrentino, B. Canard, P.V. Konarev, D.I. Svergun, X. de Lamballerie, B. Coutard, A.A. Khromykh and M. Bolognesi, J. Mol. Biol., 372, 444 (2007); https://doi.org/10.1016/j.jmb.2007.06.055.

5. C.M. Byrd, D.W. Grosenbach, A. Berhanu, D. Dai, K.F. Jones, K.B. Cardwell, C. Schneider, G. Yang, S. Tyavanagimatt, C. Harver, K.A. Wineinger, J. Page, E. Stavale, M.A. Stone, K.P. Fuller, C. Lovejoy, J.M. Leeds, D.E. Hruby and R. Jordan, Antimicrob. Agents Chemother, 57, 1902 (2013);

https://doi.org/10.1128/AAC.02251-12.

6. D.J. Gubler, Clin. Microbiol. Rev., 11, 480 (1998); https://doi.org/10.1128/CMR.11.3.480.

7. H. Malet, M.P. Egloff, B. Selisko, R.E. Butcher, P.J. Wright, M. Roberts, A. Gruez, G. Sulzenbacher, C. Vonrhein, G. Bricogne, J.M. Mackenzie, A.A. Khromykh, A.D. Davidson and B. Canard, J. Biol. Chem., 282, 10678 (2007);

https://doi.org/10.1074/jbc.M607273200.

8. M. Stone, S. Jia, W.D. Heo, T. Meyer and K.V. Konan, J. Virol., 81, 4551 (2007); https://doi.org/10.1128/JVI.01366-06

9. Y. Yan, Y. Li, S. Munshi, V. Sardana, J.L. Cole, M. Sardana, L.C. Kuo, Z. Chen, C. Steinkuehler, L. Tomei and R.D. Francesco, Protein Sci., 7, 837 (1998);

https://doi.org/10.1002/pro.5560070402.

10. D. Eldemire-Shearer, West Indian Med. J., 57, 577 (2008).

11. R.J. Kuhn, W. Zhang, M.G. Rossmann, S.V. Pletnev, J. Corver, E. Lenches, C.T. Jones, S. Mukhopadhyay, P.R. Chipman, E.G. Strauss, T.S. Baker and J.H. Strauss, Cell, 108, 717 (2002); https://doi.org/10.1016/S0092-8674(02)00660-8

12. S. Mukhopadhyay, R.J. Kuhn and M.G. Rossmann, Nat. Rev. Microbiol., 3, 13 (2005);

https://doi.org/10.1038/nrmicro1067.

13. L. Esteva and C. Vargas, J. Math. Biol., 46, 31 (2003); https://doi.org/10.1007/s00285-002-0168-4.

14. M.G. Guzman, S.B. Halstead, H. Artsob, P. Buchy, J. Farrar, D.J. Gubler, E. Hunsperger, A. Kroeger, H.S. Margolis, E. Martínez, M.B. Nathan, J.L. Pelegrino, C. Simmons, S. Yoksan and R.W. Peeling, Nat. Rev. Microbiol., 8(12Suppl.), S7 (2010);

https://doi.org/10.1038/nrmicro2460.

15. K.I.P.J. Hidari and T. Suzuki, Trop. Med. Health, 39(4Suppl.), S37 (2011); https://doi.org/10.2149/tmh.2011-S03.

16. A. Rodenhuis-Zybert, J. Wilschut and J.M. Smit, Cell. Mol. Life Sci., 67, 2773 (2010); https://doi.org/10.1007/s00018-010-0357-z.

17. S.N. Bennett, E.C. Holmes, M. Chirivella, D.M. Rodriguez, M. Beltran, V. Vorndam, D.J. Gubler and W.O. McMillan, J. Gen. Virol., 87, 885 (2006); https://doi.org/10.1099/vir.0.81309-0.

18. D. Luo, T. Xu, C. Hunke, G. Grüber, S.G. Vasudevan and J. Lescar, J. Virol., 82, 173 (2008); https://doi.org/10.1128/JVI.01788-07.

19. C.F. Macrae, P.R. Edgington, P. McCabe, E. Pidcock, G.P. Shields, R. Taylor, M. Towler and J. van de Streek, J. Appl. Cryst., 39, 453 (2006); https://doi.org/10.1107/S002188980600731X.

20. O. Trott and A.J. Olson, J. Comput. Chem., 31, 455 (2010); https://doi.org/10.1002/jcc.21334. 